\title{
The Application of Authentic Assessment to Improve the Learning Outcomes of Science in the fourth-grade students of SD Negeri 2 Pupuan
}

\author{
Pt. July Arta Eka Wiana1, ${ }^{*}$, I Kt. Gading2 ${ }^{2}$, Nym. Kusmariyatni ${ }^{3}$ \\ ${ }^{1}$ Departement of Primary School Teacher Education. Universitas Pendidikan Ganesha \\ ${ }^{2}$ Counselling Department. Universitas Pendidikan Ganesha \\ ${ }^{3}$ Departement of Primary School Teacher Education. Universitas Pendidikan Ganesha
}

\begin{abstract}
This study is aimed at improving students' learning outcomes in science in the fourth grade of SD Negeri 2 Pupuan District Tegallalang, Gianyar in the academic year of 2014/2015 after the implementation of authentic assessment. This research is a classroom action research conducted in two cycles. Each cycle consisted of four stages, namely planning, action, observation/ evaluation, and reflection. The subjects were students of class IV SD Negeri 2 Pupuan District Tegallalang, Gianyar in the academic year 2014/2015 which amounted to 15 people, consisting of 8 boys and 7 girls. The data of the learning outcomes were obtained by using the test method and analyzed with descriptive statistical analysis techniques. The results of this study were found that the application of authentic assessment can improve students' learning outcomes in science in the fourth grade of SD Negeri 2 Pupuan District Tegallalang, Gianyar 2014/2015 with an average score of learning outcomes at the end of the first cycle reached 62.27 belonged to enough category and the average score of learning outcomes at the end of the second cycle reached 69.33 which was located in the good category.
\end{abstract}

\section{Keywords:}

Authentic assessment,

Learning outcomes,

Science

\section{Introduction}

Based on Law No. 20, 2003 Chapter 1 Article 1 it states that education is "conscious and deliberate effort to create an atmosphere of learning and the learning process so that learners are actively developing the potential for them to have the spiritual power of religion, self-control, intelligence, character, and skills needed by themselves, community, nation, and country ". Thus, to improve the quality of education it is needed to create an atmosphere of learning and quality learning process by making the renewal of models, methods, approaches and media, as well as how to evaluate teachers in the learning process.

Innovation in education has been widely pursued by the government, both in the primary, secondary to tertiary education to improve the quality of education. For example, improving the quality of teacher-upgrading through courses, educational seminars, and continuing education. In addition, innovations in learning have been much done as learning through computer simulations, student learning is active or process skills approach. But yet to show significantly improved results. Indeed, many efforts have been taken by the government in order to improve the quality of education, particularly at primary school level (SD), which include the allocation of funds for education, curriculum changes, improving the quality of primary school teachers, the procurement for learning and learning resources. In addition, there are several critical success factors in improving the quality of education in primary schools, they are: the learning process, teachers, students, facilities and infrastructure of learning and how to evaluate teachers, social environment of students in the school, the school curriculum, and learning resources (Dimyanti and Moedjiono, 1994: 248). From the critical success factors, the learning process is one of the most important factors. If the learning process goes well, supported by other success factors, it will make students qualified to compete in the era of globalization.

\footnotetext{
* Corresponding author.

E-mail Addresses: juliarta@yahoo.com (Pt. July Arta Eka Wiana), ketutgading35@gmail.com (I Kt. Gading), nyomankusmariyatni@yahoo.co.id (Nym.

Kusmariyatni)
} 
Competence of students as a result of a process of meaningful learning was then recorded in a systematic and procedural through authentic assessment system. Authentic assessment can be defined as a system of assessment that requires students to combine its competence to solve problems in real life and his professional life in the future (Gulikers, 2004: 67). In line with Kunandar (2014) also revealed that authentic assessment is a set of tasks or tests that were able to establish a connection between what is in the daily lives of students with ideas developed at the school. In order to realize the great mission of authentic assessment of government through the Minister of Education and Culture (Permendikbud) number 66 of 2013 on the assessment standards governing the conduct of authentic assessment in schools.

Teachers should ideally carry out the study. In the learning, interaction occurs between teacherstudent, student-student, and student-teacher. For that, it is a must to students and teachers carry out their respective roles. Teachers make students learn and students learn how to learn. In other words, the learning should have multidirectional interactions (Dimyanti and Mudjiono, 1994). Multidirectional interaction will occur when teachers have been preparing for administration, materials, and instructional media representative to be used in carrying out the teaching. During the implementation of learning, a teacher has skillfully used eight teaching skills and at the end of the lesson, the teacher has found the base. Science teaching in primary schools is a solid foundation to enable students to enter higher education and also to face the challenges of the development of Science and Technology (Science and Technology).

If viewed more deeply, essentially learning "Science is a learning associated with the phenomena of the universe" (Suma, et al., 2001). Further elaborated, learning science is often said science experiments. Experts observe natural phenomena and try to find the events and principles that connect these phenomena. Learning science is not a collection of facts and principles. Learning science requires a lot of observation of phenomena, deep and precise measurement, broad and deep experimentation and precise predictions. In accordance with the nature of the science subject, it is not enough just to learn science through a collection of facts, principles, laws and theories but also must involve the process of how the body of knowledge was obtained. This shows that the activities of the experiment (investigation) are an integral part of learning science that can be said to be the spirit of learning science. In the experimental activity (investigations), students can work in a group whose members are heterogeneous in terms of both ability and the sex. The philosophy underlying the model of cooperative learning in education is the philosophy of homo hominine socius. This philosophy emphasizes that human beings are social creatures.

Learning science is a part of humans' life since the human beings know themselves and the natural surroundings. Humans and the environment are the sources, object, and science subject. Science education is one aspect of education that uses science as a tool to achieve the goal of education in general and science in particular educational goals. Science subjects emphasize providing a direct experience that is expected to develop competencies that students are able to explore and understand the universe around scientifically (Ward, 2013). According to Suastra (2009) the nature of science consists of 3 dimensions, namely: scientific attitude, scientific products, and scientific processes. (1) The attitude of the scientific, meaning that learning science requires the desire to know, the attitude of willing to get a new attitude of cooperation, attitude is not desperate, the attitude is not an ancient thought, the attitude of introspection, a responsible attitude, free thinking attitude, and the attitude of discipline self; (2) Science as scientific products, the expected student learning to understand the phenomena, facts, concepts, and theories that have been studied; (3) Science as a scientific process, meaning that students are expected to find their own experience or learn something so that later it can be applied in everyday life. This includes the skills needed to obtain and develop science.

Science subjects in primary schools are expected to become a vehicle for students to learn about themselves and the natural surroundings as well as prospects for further development in applying it in our daily lives. The learning process emphasizes providing direct experience to develop competencies in order to explore and understand the universe around scientifically. Science teaching in primary schools needs to emphasize learning Salingtemas (science, environment, technology, and society) which is directed on the learning experience directly through the use and development of process skills to design and create a masterpiece through the application of science concepts and competencies scientific work wisely. So it is to foster the ability to think, work and communicate scientific attitude as well as an important aspect of life skills.

Based on observations made at SD Negeri 2 Pupuan in the fourth-grade, passive students can be seen in the following study. It can be said that the majority of students understood a little about science subjects. In addition, the level of confidence of students was still low. Based on interviews conducted with teachers, who were teaching science, the findings showed that in the learning process students did not understand the lessons. In which, it can result in lower student learning outcomes. Data about the low 
results of fourth-grade students learning science in SD Negeri 2 Pupuan were also supported by the results of the early reflections conducted by researchers. Based on the results of these initial reflections, the findings obtained an average value of learning outcomes in the early reflections of science amounted to 54.97 with a new classical completeness achieved is $55.33 \%$. In addition to this, in the implementation of science teaching in the classroom, the evaluation and implementation were of a separate study. That is, the evaluation was carried out only at the end of the learning activities.

Evaluations conducted so far by the teacher were more likely to refer to the final result only (practical reports). The process for students to find conclusions from the results of learning activities was not assessed. Once the investigation was complete, the activities and the results were obtained, then students were asked to make a report. After reports were collected, the students were given a test. The tests given by teachers were the tests that had been experimented and associated with the material. The provision of such testing would only assess one aspect (namely cognitive), whereas affective and psychomotor aspects were ignored. This will result in a lack of student interest in conducting an investigation, they consider the resulting value is only of taking the test itself so that in the process of doing it, they were not serious, they often joked and interfered the other groups. Based on interviews with some of the teachers in the study, there were some reasons they only rate a product. These reasons were: (1) the number of students was relatively large and required too much time rating, so it took extra effort to do the assessment process and (2) the difficulty in making the assessment sheet.

Assessment or evaluation is one stage in the cycle of learning that its role can not be ignored. It is said so because the minimum evaluation can result in two things: (1) as feedback in the learning process, and (2) to provide information about the quality of the acquisition on the subject of education. In accordance with the rule, in the process of science learning between process and product must be balanced. If it is associated to an evaluation, then it should be in the learning process, the implementation of the evaluation should not be in the end (judging products only) but the process to produce the product must be assessed as well.

A good assessment is an integral part of good teaching. A proper assessment at least oriented to two main priorities: (1) the main purpose of education, ie learning how to learn from an experience, in order to plan the next learning becomes meaningful, and (2) accommodating diversity of learners primarily in terms of learning styles in order to help improvement planning process of learning. Furthermore, in connection to the assessment of students, Kurikulum Tingkat Satuan Pendidikan mentioned that during the learning process, teachers monitor students' participation or participation from the beginning to the end of learning. Another implication of the implementation of standards of competence is a teacher must develop sustainable authentic assessment (continuous authentic assessment) which ensures the attainment and mastery of competencies. Authentic assessment is the assessment carried out in a non-threatening atmosphere. This assessment is a process of gathering information by teachers about the progress and achievement of pupils learning is done through various techniques are able to express, to prove or to show exactly that learning objectives and abilities (competencies) has been completely controlled and accomplished.

Authentic assessment has the properties: (1) a competency-based; (2) a student-centered; (3) integrated into the learning process; (4) on-going and sustainable (Compiler Team, 2008: 23). Further explained, the characteristics of authentic assessment are: (1) carried out during and after the learning process takes place; (2) can be used for formative and summative; (3) measured knowledge and skills; (4) sustainable; (5) integrated; and (6) can be used as feedback. The types of authentic assessment included performance assessment, self-assessment, essay, project assessment, product assessment, and portfolios. The activities included observation of authentic assessment (observation), presentations, discussions, interviews, and others. Assessment activities that are not authentic are like a multiple choice objective test, memorizing material, and other activities that only require students mechanically and they were not directly related to the life (Marhaeni, 2008).

Mueller (in Nurgiyantoro, 2008: 254) states that "authentic assessment applied in the learning process can provide some benefits". The benefits derived from the implementation of authentic assessment as follows. (1) the use of authentic assessment allows direct measurement of the performance of the learner as an indicator of achievement of competence that is learned. A measurement that only measures the learner's knowledge was considered as indirect. However, authentic assessment requires learners to demonstrate, work in a concrete and also meaningful situation that automatically reflects the mastery and the skills. The direct performance is directly related to the context of real-world situations and it can also be observed directly. It was more reflective of the level of achievement in the areas studied. (2) the authentic assessment gives learners the opportunity to construct the learning results. Assessment should not merely ask learners to repeat what they have learned as they train thus they merely memorize and recall memories, and it is less meaningful. With authentic assessment, learners are asked to construct 
what is achieved when they are faced with a concrete situation. In this way, the learner will select and prepare answers based on knowledge and analysis of the situation so that the answer is relevant and meaningful. (3)it allows the integration of authentic assessment activities of teaching, learning and assessment activities into one integrated package. In traditional learning, as well as traditional valuation models, between teaching and assessment activities is something separated, or deliberately separated. However, it is not the case with the model of authentic assessment.

From some forms of assessment processes that have been mentioned above, it is considered that authentic assessment can improve learning outcomes. Implementation of authentic assessment is no longer using the traditional assessment formats (multiple-choice, matching, true-false, and paper and pencil test), but using a format that allows students to complete a task or demonstrate a performance in solving a problem. The format of this assessment can be: (1) test that presents objects or events native to the presence of students (hands-on assessment), (2) the task (task skills, simple task investigation and investigation of integrated task), (3) the recording format of revision of students (for example: portfolios, interviews, checklists). In the authentic assessment of students it will be involved in the activities to practice how to apply the knowledge and skills to new tasks. The assessment process involves a variety of activities such as oral interview, problem-solving either individually or in groups, performance, and creative writing of portfolio. In authentic assessment, rote learning and passive test did not happen but the students were involved in activities such as doing science experiments, social research, writing stories and reports, read and interpret literature, and solve the problems applicably.

Based on the above explanation, it appears that authentic assessment functions to improve learning outcomes of science subject. However, empirical results are not yet known. To determine empirically whether authentic assessment functions to improve learning outcomes of science subject, this study was conducted in the fourth-grade students of SD Negeri 2 Pupuan District Tegallalang, Gianyar in the academic year 2014/2015.

\section{Method}

This research included a Class Action Research (Classroom Action Research). According to Suharsimi, et al. (2009: 3) action research is defined as "a scrutiny of the learning activities in the form of an action, which is deliberately raised and occur in a classroom together". Meanwhile, according to Supardi, et al (2009: 104) they argue that action research is "an approach to improve education by making changes towards the improvement of education and learning outcomes". Based on these definitions, we can conclude that action research is an act that is raised in the classroom to improve teaching practices in order to improve the quality of learning.

In this classroom action research, there are four stages in the research cycle. The four phases consist of planning, implementation, evaluation/ observation, reflection. The research was carried out in one cycle. If the first cycle of the studies does not work then it is continued with the next cycle. The next cycle consists of a revised planning, action, observation/ evaluation, and reflection

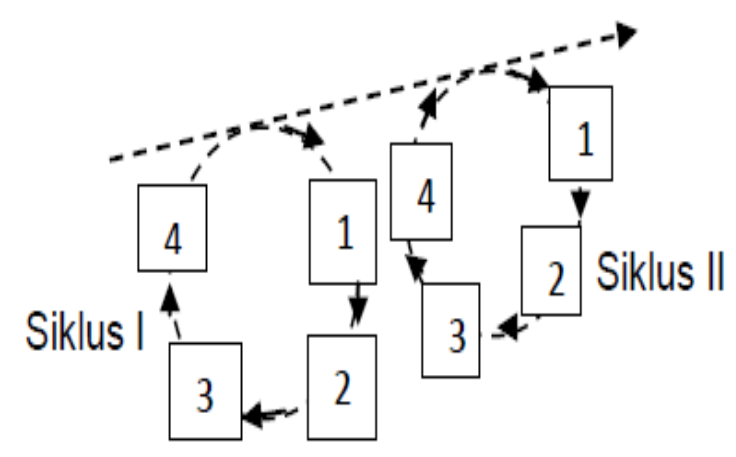

(Source: Adapted from Agung, 2005: 91)

Figure 1 Stages of Two-cycled Action Research

The experiment was conducted in SD Negeri 2 Pupuan with research subjects are students of class IV by the number of students studied was 15 people, consisting of 8 boys and 7 girls. While the object of study is the result of learning science in the fourth grade of SD Negeri 2 Pupuan, District Tegallalang, Gianyar in the academic year 2014/2015. 
The data collected in this study are data on learning outcomes science subject. For the students, science learning test method is used. The test method is a way of obtaining data in the form of a task that must be done by a person or groups of people who were tested. The test can produce a score that is then compared with certain criteria. In this study, data were collected by a test for each individual. Science subject achievement test constructed in the form of an essay. The collected data were analyzed using descriptive statistical analysis methods. The data on achievement test steps are as follows: analyzing the data mastery learning students individually, calculating the average value of the class, and specifying the percentage in the classical learning completeness

\section{Results and Discussion}

This research was conducted with success criteria if the achievement of mastery of the material has reached $50 \%$ of individuals and $75 \%$ in the classical style. If these criteria have been met, this study will be stopped. Based on these criteria, the results obtained in this study are as follows. The results of the data analysis on the early reflections show that the average value of science learning outcomes in the early reflections was at 54.97 and a standard deviation of 11.81. If each student learning outcomes was compared to standard minimum mastery learning outcomes in SD Negeri 2 Pupuan that was equal to 50, then there were seven other students considered failing. This meant that the new classical completeness achieved was $55.33 \%$. If the result was translated using the criteria of competence mastery level prevailing in SD Negeri 2 Pupuan for science subjects, it was in the range 55-69 in the category of enough.

The results of data analysis in the first cycle showed that the average value of learning outcomes science subject was at 62.27 with classical completeness $67 \%$. Completeness of classical study in the first cycle, when it was converted into the level of mastery of competencies applicable in SD Negeri 2 Pupuan for science education subjects, were in the range 55-69 that belonged to the category of enough. These results did not meet the $75 \%$ minimum indicators for classical learning completeness. To that end, the study continued to the second cycle.

The results of data analysis in the second cycle showed that the average value of learning outcomes science subject was at 69.33 with classical completeness $80 \%$, which meant completeness classical study had an increase of $13 \%$ from cycle I. The results in this second cycle indicators had met at least $75 \%$ for classical learning completeness. If the results were converted into a level of mastery of competencies applicable in SD Negeri 2 Pupuan for science education subjects that were in the range of 70-84 residing in either category. Because of the thoroughness of student learning outcomes already achieved the desired results in the second cycle, the study was discontinued. This study showed that the application of authentic assessment to improve learning outcomes science subject fourth grade students of SD Negeri 2 Pupuan District Tegallalang, Gianyar in the academic year 2014/2015. The results obtained by the data analysis have been done before. At the time of initial observations, prior to the implementation, it was known that the fourth-grade students' science learning still did not meet minimum completeness criteria (KKM) determined by researchers at 50 to the average grade and $75 \%$ for mastery in classical. While the average value obtained by the students in the classical completeness 54.97 and reached 55.33\%. Seeing these conditions, it needs to be improved towards quality of teaching in the classroom.

At the beginning of the first cycle, the class consisted of 15 students divided into three heterogeneous groups in terms of both academic ability and gender. Quantitatively, the average value of the results in learning science from the students in the first cycle was 62.27 and classical completeness of students' learning outcomes of science subject was $67 \%$. These results indicated that a classical completeness achieved in the first cycle had not met the criteria of success, and there were still deficiencies during the learning process in cycle I. As for the deficiencies identified in the implementation of the first cycle of action: (1) students were still stiff, tense, and less relaxed in the learning process. This is because the teacher strategies used in delivering course material were different. This, of course, caused students to feel something new in their learning environment, (2) the student had not been able to set the time in tasks assigned by the teacher, so that when the allotted time had expired, the task had not been completed, (3). the students were not familiar with the use of authentic assessment involving higher-level thinking skills and covering broad knowledge and the students were not yet aware of what to do to be assessed in authentic assessment. This is because students were already familiar with the usual traditional assessment applied by the teacher.

Based on the shortcomings encountered in the first cycle, researchers together with teachers discuss things for further improvements implemented in the second cycle.

Repair action taken was (1) to motivate each student to make a positive impression on students, using statements that were positive to be able to relieve tension of the students about the impression that 
science subjects were difficult to understand, (2) to remind students to be actively involved in completing the task group when given so that the task was completed on time. In addition, to familiarize students to answer the questions that were considered easy, so that the time required to do the problems was precise with the time allowed, (3) provide further insight to students about authentic assessment that involved high level of thinking skills and include knowledge and sensitize students about what to do to be assessed. The implementation of the action on the second cycle adapted to reflect the results of the first cycle by doing some remedial action. Improvement actions implemented in the second cycle turned in quantity to improve students' learning outcomes of science subject. In the second cycle, the average value obtained from the students' science learning was by 69.33 and completeness of students in a classical peaked at $80 \%$, so the learning result of the implementation of the second cycle already met the indicators that had been determined and had been increased from cycle to cycle. This was evident from the average results of fourth-grade students learn science an increase of 7.06 from the first cycle to the second cycle. Similarly, in classical learning completeness an increase of $13 \%$ from the first cycle to the second cycle was found. Because of the thoroughness of students' learning outcomes already achieved the desired results in the second cycle, the study was discontinued and the results obtained were recommended as reports and given to the teacher concerned. Some things that can be used as a reflection on the second cycle were as follows. (1). Students were already seen to be stiff and relaxed in the learning process by using authentic assessment. Students also had shown the courage to express opinions either when the teacher gave the questions or when discussing in groups. (2). Students were already able to set the time on the tasks assigned by the teacher. This was because teachers already gave guidance to each group about how to set the time on task. (3) The seriousness of the students in participating in learning had improved. This can be seen when the learning took place, no student was tinkering. They all felt happy to follow learning with authentic assessment.

These results were consistent with the theory that stated that authentic assessment monitors and measures students' skills in a variety of possibilities for solving the problems encountered in real world situations or contexts. Assessment can create active learners build knowledge, and to form competence as specified in the SKL, SK, KD, and indicators of achievement. Thus, authentic assessment assesses the real capabilities of students in relation to everyday life (Marhaeni, 2008: 2). In line with these opinions Nurgiyantoro (2001: 4) also added that authentic assessment is to measure, monitor and evaluate all aspects of the learning outcomes (which is included in the domains of cognitive, affective, and psychomotor), both of which appeared to be the end result of a process of learning, as well as in the form of changes and development activities and the acquisition of learning during the learning process in the classroom and outside the classroom. In essence, the assessment activities carried out were not solely to assess students' learning outcomes, but also a variety of other factors in one lesson activity itself. That was, based on the information obtained from the assessment; it could also be used as a feedback rating of the teaching activity that was carried out.

These findings supported previous research findings conducted by Pharhyuna (2012) which stated that there were differences in the English language letter writing skills among students who followed the model of problem-based learning and authentic assessment with students who took the direct learning model and conventional assessment. Other studies put forward by Ardana (2011) that was Authentic Assessment Model Development and Learning for Mathematics oriented on Cognitive Style and Culture for Elementary School Students in Bali Province. Through the results of this study, it was shown that the absorption and mastery learning achieved was greater than the established criteria which were greater than the absorption of $65 \%$, and $85 \%$ completeness study. In other words, it could be said that student achievement was quite good. Meanwhile, 90 students (94.74\%) gave positive responses and only 3 students (5.26\%) gave negative feedback on the implementation of learning. Due to the positive response that was of $94.74 \%>85 \%$.

\section{Conclusions}

Based on test results from the data obtained, it could be concluded that the application of authentic assessment could improve student learning outcomes in science teaching in the fourth grade of SD Negeri 2 Pupuan District Tegallalang, Gianyar in the academic year 2014/2015. It could be seen from the average value of learning outcomes that had met the success criteria set out in this study, the value of minimum completeness criteria (KKM) was of 50 and a classical completeness (KK) was by $75 \%$. In preliminary tests, the average value of learning outcomes of science subject was 54.97 , and $55.33 \%$ for the classical completeness. After the first cycle, the average value of learning outcomes of science subject became 62.27 and classical completeness moved to $67 \%$. After the second cycle, the average value of learning outcomes of science subject became 69.33 and classical completeness was $80 \%$. 
Based on the findings described above, some suggestions could be given as follows: 1) Through the implementation of authentic assessment, it is expected that students' learning outcomes can be improved optimally in science subjects. 2) Through the application of authentic assessment, it is expected that the professionalism of teachers can be improved in managing the process of learning science. 3) For other researchers who are interested in doing deeper researches into the factors that influence learning outcomes in science subjects in primary schools.

\section{References}

Ardana, I Made. (2011). Pengembangan Model dan Asesmen Otentik Pembelajaran Matematika Berorientasi Gaya Kognitif dan Budaya untuk Siswa Sekolah Dasar di Provinsi Bali. Tersedia pada https://lemlitundiksha.wordpress.co m/tag/asesmen-otentik/. (diakses pada tanggal 11 desember 2011).

Arikunto, Suharsimi. (2009). Prosedur Penelitian Suatu pendekatan praktek. Jakarta: Rineka Cipta.

Dimyanti dan Moedjiono. 1994. Belajar dan Pembelajaran. Jakarta: Proyek Pembinaan dan Peningkatan Tenaga Kependidikan.

Marhaeni, A.A.I.N. (2008). Tinjauan Teoritis Mengenai Asesmen Otentik dan Implementasinya dalam Pembelajaran. Makalah. Disampaikan dalam Seminar tentang Profesionalisme Guru dan Inovasi Pembelajaran.

Nurgiyantoro. (2001). Penilaian dalam Pengajaran Bahasa Indonesia.Yogyakarta:

----. 2008. Penilaian Otentik. Jurnal Cakrawala Pendidikan. November 2008, Th. XXVII, No. 3.

Pharhyuna, Jaya. Pengaruh Model Pembelajaran Berbasis Masalah dan Asesmen Otentik terhadap Keterampilan Menulis Berbahasa Inggris ditinjau dari Kreativitas Siswa SMK Negeri 1 Singaraja. Tesis (tidak diterbitkan). Pasca Undiksha Singaraja.

Suastra, I.W. (2009). Pembelajaran Sains Terkini: Mendekatkan Siswa dengan Lingkungan Alamiah dan Sosial Budayanya. Universitas Pendidikan Ganesha. Singaraja.

Suma, dkk. 2001. "Penerapan Eksperimen Terbuka Terbimbing dalam Pembelajaran Fisika Dasar pada Mahasiswa TPB Jurusan Pendidikan MIPA IKIP Negeri Singaraja". Laporan Penelitian. Singaraja: Universitas Pendidikan Ganesha.

Supardi. (2009). Penelitian Tindakan Kelas. Jakarta: Bumi Aksara.

Tim Penyusun. 2008. Materi Pendidikan dan Latihan Profesi Guru (PLPG) Asesmen. Singaraja: Universitas Pendidikan Ganesha.

Wardana. I Wayan. (2013). Pengaruh Model Pembelajaran Group Investigation (GI) Berbantuan Asesmen Proyek terhadap prestasi belajar IPA siswa kelas V tahun pelajaran 2012/2013 sekolah dasar di Gugus III Tampaksiring Kabupaten Gianyar. Skripsi (tidak diterbitkan). Singaraja fakultas ilmu pendidikan. UNDIKSHA 